\title{
Challenges of Future Jobs in Macedonia - Remote or Hybrid Generation?
}

\author{
Gelecekteki İslerin Zorluklarl - Uzaktan veya Hibrit Üretim?
}

\author{
Marija APOSTOLOVA NIKOLOVSKA \\ Phd., State Counselor for Human Resources, \\ Government of the Republic of N. Macedonia, \\ marija.apostolova@primeminister.gov.mk \\ https://orcid.org/0000-0002-1758-3471
}

Makale Başvuru Tarihi: 26.02.2021

Makale Kabul Tarihi: 23.12.2021

Makale Türü: Araştırma Makalesi

\section{Nadezda DIMITROVSKA}

Spc., State Counselor for Information Technology, Government of the Republic of N. Macedonia, nadezda.dimitrovska@gs.gov.mk https://orcid.org/0000-0002-0723-2045

$\begin{aligned} & \text { Anahtar } \\ & \text { Kelimeler: }\end{aligned}$
Teknolojik
Değişiklikler,
İşler,
Uzaktan Üretim,
Hibrit Üretim,

Hibrit Uretim,

\section{ÖZET}

Araştırma konusu güncel, çağdaş ve ampirik olup, mevcut ve gelecekteki araştırmactlar için de bir zorluğu ortaya koymaktadır. Bu makale, literatürdeki çalışmalara ve son dönemdeki birçok araştırmalara göre işin ve işgücünün geleceği ile ilgili çeşitli araştırma soruların teorik olarak analiz eder: "İnovasyondaki mevcut işgücü bugüne göre nasıl benzersiz olabilir?" "Meslekler ve işler nasıl değişebilir?" "Hangi yetenekler ve kapasiteler gerekli olacak?” Bilgi teknolojisindeki değişiklikler aynı zamanda șirketlerdeki işin niteliğini ve Makedonya'daki kurumlarda görev alan yöneticilerin çalışmasını da değiştirmektedir. Makalede öncelikle Makedonya resmi istatistik verileri kullanılmıştır. Yüksek teknolojinin getirilmesi ve çok sayıda işin bilgisayarlaştırılması, işin bilişsel bileşenlerinin analiz edilmesi ihtiyacını göstermektedir. Ancak, değişiklikler yalnızca işlerle ilgili olarak gerçekleşmeyecek; kendimizi organize etme şeklimizde de değişiklikler olacaktır. Ayrıca makalede Makedonya'da son beş yılda faaliyet gösteren sektörlere göre çalışanların durumunun bir analizi yapılmaktadır. Aynı zamanda çalı̧̧an sayısında artış olan sektörler de analiz edilmektedir. Verilere göre, Makedonya'da geçmiş dönemde meydana gelen sosyal ve teknolojik değişikliklerin özellikle tarım, ormancılık ve balıkçılık sektöründeki çalışan sayısı üzerinde faaliyet gösterdiği sektörler itibarlyla çalışan sayısı üzerinde güçlü bir etkiye sahip olduğu vurgulanmaktadır. Çalışan sayısı 24758 kişi azalırken, son beş yılda imalat sektöründe çalışan sayısı 20520 artmıştır.

Keywords:

Technological

Changes,

Jobs,

Remote Generation,

Hybrid Generation,

\begin{abstract}
The subject of research is current, contemporary, empirical and is a challenge for a number of current and future researchers. This paper theoretically analyzes several research questions regarding the future of work and jobs according to relevant studies and many researches in the last period: How might the current labor force in innovation be unique in relation to today? How might occupations and jobs change? What abilities and capacities will be required? The changes in the information technology also change the nature of the work in the company and with it the work of the manager in the institutions in N. Macedonia. The paper uses official statistical data from N. Macedonia, primarily due to their availability. The introduction of high technology and computerization of a large number of jobs indicate the need for analysis of the cognitive components of the job. However, the changes will not only happen in relation to the jobs; there will also be changes in the way we organize ourselves. The paper also presents an analysis of the situation in $N$. Macedonia of employees according to the sectors of activity in the past five years, at the same time an analysis is made of the sectors in which there is an increase in the number of employees. According to the data, it is emphasized that the social and technological changes that occur in the past period in $N$. Macedonia have a strong impact on the number of employees by sectors of activity especially on the number of employees in the sector of agriculture, forestry and fishing where the number of employees decreased by 24758 persons, while in the last five years the number of employees in the manufacturing sector has increased by 20520.
\end{abstract}




\section{INTRODUCTION}

Today, the universe of work is encountering a time of shocking change. As robotization, fundamentally as mechanical technology, man-made consciousness and other new advances, are making at a remarkable rate and are altogether affecting various businesses in N. Macedonia, they are heading to wide-going changes to the positions, errands and abilities needed inside every area. Simultaneously, various different parts, for example, work versatility and movement; segment change; changes in the conveyance and nature of instruction and abilities and developing ability needs in areas like framework, medical care and schooling are too changing the nature and nature of work. The cooperation can be virtual or individual, contingent upon the job, extent of work and action. The versatile, on-request labor force will be a future model inside the coordinations business, tallying both operational and office positions.

The paper is research-instructive in nature and gives a complete overview of a number of other review research that refer to and complement the research subject contained in the title of this paper. Starting from the topicality, modernity and the need, this doctoral thesis is focused as it is resolving some of the dilemmas and issues that arise from the subject. Starting from the topicality, modernity and the need, this paper is focused as it is resolving some of the dilemmas and issues that arise from the subject. Regarding the scientific-research methods in the paper, the emphasis is placed on the descriptive, analytical-synthetic and empirical method in order to discover and explain the situation of employees in N. Macedonia in the period from 2016 to 2020 in terms of sectors of activity, as well as for 2019. and 2020 in terms of employment rate, education and number of vacancies. For better visibility of the statistical data, they are presented with graphs and tables, additionally a percentage is calculated. The literature used in the paper is directly related to the subject of the research directly refers to a number of empirical facts about the labor market in N. Macedonia, but also about the challenges of the jobs, abilities and skills that will be needed in the future, and are part of the latest world reports.

\section{THE MEANING OF THE FUTURE JOB - WHAT ABILITIES AND CAPACITIES WILL BE REQUIRED?}

The most profound changes in work can result from changes in societal values. At the moment, the workforce is aging, or more precisely, the average age of workers is increasing in N. Macedonia. In addition to demographic change, there may be changes in the role that work plays in life. The amount of education that the average person receives is steadily increasing since the industrial revolution, and it seems that this trend will continue. One undesirable effect of the increase in education is that the people who are well educated want and expect a job that they consider important. In next period, preparing and upskilling will be significant for organizations to remain on top of things in the new time of work. Institutional information is basic for keeping up coherence and enduring an emergency. Upskilling existing workers should get known as a keen path for establishments and organizations to clutch that knowledge while developing abilities to address new difficulties.

A comparative analysis of the data shows that in the last five years the number of employees in the larger number of sectors is increasing and the percentages are shown in Table 1, especially in the manufacturing, wholesale and retail trade sectors and in social and health care.

Table 1. Employed By Sectors of Activities And By Type of Ownership of the Business Entities

\begin{tabular}{|c|c|c|c|c|c|c|}
\hline Year & 2016 & 2017 & 2018 & 2019 & 2020 & $\%$ \\
\hline Agriculture, forestry and fishing & 120303 & 120311 & 119337 & 111033 & 95545 & 1.26 \\
\hline Mining and quarrying & 6416 & 6576 & 6509 & 6587 & 6977 & 0.92 \\
\hline Manufacturing & 137615 & 143253 & 150820 & 157831 & 158135 & 0.87 \\
\hline Electricity, gas, steam and air conditioning supply & 10358 & 10407 & 10324 & 10610 & 9395 & 1.10 \\
\hline Water supply, sewerage, waste management and remediation activities & 12797 & 12651 & 14120 & 17214 & 15590 & 0.82 \\
\hline Construction & 52140 & 53391 & 56263 & 56036 & 55165 & 0.95 \\
\hline Wholesale and retail trade, repair of motor vehicles and motorcycles & 104514 & 108869 & 108726 & 112624 & 116970 & 0.89 \\
\hline Transportation and storage & 36258 & 37769 & 39134 & 44410 & 43348 & 0.84 \\
\hline Accommodation and food service activities & 25446 & 28569 & 30964 & 34333 & 33799 & 0.75 \\
\hline
\end{tabular}


APOSTOLOVA NIKOLOVSKA, Marija ve DIMITROVSKA, Nadezda - Challenges of Future Jobs in Macedonia - Remote or Hybrid

\begin{tabular}{|c|c|c|c|c|c|c|}
\hline Information and communication & 13600 & 13587 & 12995 & 15348 & 18481 & 0.74 \\
\hline Financial and insurance activities & 10927 & 10817 & 8095 & 10627 & 11844 & 0.92 \\
\hline Real estate activities & $(1615)$ & $(1702)$ & $:$ & 2093 & 2168 & 0.74 \\
\hline Professional, scientific and technical activities & 13496 & 13350 & 17332 & 18480 & 18550 & 0.73 \\
\hline Administrative and support service activities & 14335 & 13928 & 14612 & 20651 & 20067 & 0.71 \\
\hline Public administration and defence, compulsory social security & 53969 & 53143 & 52900 & 53425 & 54962 & 0.98 \\
\hline Education & 42569 & 43973 & 44696 & 46186 & 48824 & 0.87 \\
\hline Human health and social work activities & 39089 & 40807 & 42760 & 45279 & 49683 & 0.79 \\
\hline Arts, entertainment and recreation & 12584 & 13262 & 12334 & 17773 & 18391 & 0.68 \\
\hline Other service activities & 13538 & 12604 & 13059 & 14875 & 15631 & 0.87 \\
\hline
\end{tabular}

Source: Republic of N. Macedonia. State Statistical Office. Active Population in the Republic of N. Macedonia

Table 2. Labour Force and Activity Rates in Republic of N. Macedonia

\begin{tabular}{|c|c|c|c|c|c|c|c|}
\hline \multicolumn{10}{|c|}{ Labour Force And Activity Rates } \\
\hline & $\begin{array}{c}\text { Total Working } \\
\text { Age Population }\end{array}$ & Total & Employed & Unemployed & $\begin{array}{c}\text { Activity } \\
\text { Rate }\end{array}$ & $\begin{array}{c}\text { Employment } \\
\text { Rate }\end{array}$ & $\begin{array}{c}\text { Unemployment } \\
\text { Rate }\end{array}$ \\
\hline 2019 & 1684820 & 964014 & 797651 & 166363 & 57.2 & 47.3 & 17.3 \\
\hline $2019 / \mathrm{III}$ & 1685351 & 964248 & 799546 & 164702 & 57.2 & 47.4 & 17.1 \\
\hline $2020 / \mathrm{II}$ & 1685909 & 953039 & 793416 & 159623 & 56.5 & 47.1 & 16.7 \\
\hline $2020 / \mathrm{III}$ & 1685741 & 941136 & 785561 & 155575 & 55.8 & 46.6 & 16.5 \\
\hline
\end{tabular}

Source: Republic of N. Macedonia. State Statistical Office. Active Population in the Republic of N. Macedonia Results from the Labour Force Survey, III quarter 2020

Also, the data from the Macedonian State Statistical Office show that, in the III quarter of 2020, the labour force in the Republic of North Macedonia numbered 941136 persons, of which 785561 were employed and 155575 were unemployed persons.

Table 3. Labour Force by Educational Attainment

\begin{tabular}{|c|c|c|c|c|c|c|}
\hline \multirow{2}{*}{$\begin{array}{c}\text { Educational } \\
\text { Attainment }\end{array}$} & \multicolumn{2}{|c|}{ Labour Force } & \multicolumn{2}{|c|}{ Employed } & \multicolumn{2}{c|}{ Unemployed } \\
\cline { 2 - 7 } & $2019 / \mathrm{III}$ & $2020 / \mathrm{III}$ & $2019 / \mathrm{III}$ & $2020 / \mathrm{III}$ & $2019 / \mathrm{III}$ & $2020 / \mathrm{III}$ \\
\hline Without education & 9107 & $(4176)$ & $(4979)$ & $(2830)$ & $(4128)$ & $:$ \\
\hline Incomplete primary and lower secondary education & 19123 & 14004 & 15179 & 11008 & $(3943)$ & $(2996)$ \\
\hline Primary and lower secondary education & 162406 & 138770 & 123560 & 109361 & 38846 & 29409 \\
\hline 3 years of secondary education & 76301 & 70382 & 67928 & 59308 & 8373 & 11074 \\
\hline 4 years of secondary education & 462299 & 451504 & 385729 & 375969 & 76571 & 75536 \\
\hline Higher vocational education & 17261 & 18427 & 16093 & 16373 & $:$ & $(2054)$ \\
\hline University level education & $\mathbf{2 1 7 ~ 7 5 1}$ & $\mathbf{2 4 3 ~ 8 7 2}$ & $\mathbf{1 8 6 ~ 0 7 8}$ & $\mathbf{2 1 0 ~ 7 1 1}$ & $\mathbf{3 1 ~ 6 7 3}$ & $\mathbf{3 3 ~ 1 6 1}$ \\
\hline TOTAL & $\mathbf{9 6 4 ~ 2 4 8}$ & $\mathbf{9 4 1} \mathbf{1 3 6}$ & $\mathbf{7 9 9 5 4 6}$ & $\mathbf{7 8 5} \mathbf{5 6 1}$ & $\mathbf{1 6 4 7 0 2}$ & $\mathbf{1 5 5} \mathbf{5 7 5}$ \\
\hline
\end{tabular}

Source: Republic of N. Macedonia. State Statistical Office. Active Population in the Republic of N. Macedonia Results from the Labour Force Survey, III quarter 2020

Also, in the paper are given data about Macedonian labour force by educational attainment. It is important to note the increase in the number of unemployed with university level education by 1488 within one year. 


\section{RELEVANT RESEARCH}

In the report - Leading the social enterprise: Reinvent with a human focus, according to Deloitte, $90 \%$ of associations are overhauling parts, with "mixture occupations" in the most popularity; these jobs wed specialized abilities with "delicate" abilities in zones like correspondence, advantage and coordinated effort. On the opposite side, the World Economic Forum finds that more than 33\% of the abilities (35\%) considered significant in the present labor force will have changed inside five years, with delicate abilities in the working environment getting more significant and attributes like flexibility are popular as organizations change their activities to accept distant work and other crossover working environment models (Deloitte Global Human Capital Trends, 2019). Additionally, it is stressed that given developing abilities deficiencies and the low birth rate in various countries, utilizing and managing "elective" labor forces will get vital for business development in the years ahead.

In the report from World Economic Forum, it is reasoned that inventiveness will get one of the main three abilities laborers will require and furthermore enthusiastic insight, which doesn't highlight in the best 10 abilities these days, will get one of the top abilities needed by all. The main ten abilities in 2020 are: mind boggling critical thinking, basic reasoning, imagination, individuals the board, planning with others, passionate insight, judgment and dynamic, administration direction, arrangement and intellectual adaptability (World Economic Forum, 2020).

In the report from Citrix with the title Work 2035 are analyzes elective dreams of things to come of work in 2035 and how individuals and innovation will cooperate to make esteem. This report depends on a two-section research study joining elective prospects situation arranging and hearty assessment research among business pioneers and representatives across the US and Europa and recognizes four elective fates of work and thinks about how innovation will change the connection among individuals and innovation. As indicated by the distributed information $77 \%$ of experts imagine that by 2035 , AI will essentially accelerate their dynamic cycle, making them more beneficial and $75 \%$ of experts accept that in 2035, AI speculation will be the best driver of improvement for their association. The examination shows that we are near the precarious edge of some turning points in the advancing connection among individuals and innovation in the work environment and 96 percent of experts (business pioneers and laborers consolidated) accept that the opportunity will come when innovation and AI will create more income for their association than human specialists. In the closing it is pointed that 2028 is the year experts anticipate we will reach tipping point, where innovation and AI start to create more income for their associations than people (Citrix, 2020b).

As indicated by report World Economic Forum, eight fates of work have been dissected, for example eight situations and their suggestions present different potential dreams of what the eventual fate of work may resemble constantly 2030 (WEF, 2020). In light of how various mixes of three center factors;

- The pace of innovative change and its effect on plans of action,

- The advancement of learning among the current and future labor force,

- The greatness of ability portability across geologies are probably going to impact the idea of work later on.

This report gives a beginning stage to thinking about a scope of choices around the numerous potential fates of work. With respect to change, as one of the three center factors that underlined is that: ongoing developments in innovation have drastically modified numerous parts of our regular daily existences, changed whole enterprises and essentially disturbed the work market. Simultaneously it is pointed that, improvements in regions like manmade reasoning, advanced mechanics and large information investigation have uprooted entire occupations, moved the undertakings and required abilities inside couple of occupations, and made altogether new errands and occupations. Additionally, it is accentuated that, the repercussions of a large number of these mechanical improvements so far are now being felt today and as a result of that how rapidly and extensively these advancements are received and how quickly and comprehensively advance improvements influence plans of action, will decide the overall robustness or instability of future work markets. 
World Economic Forum recognizes a non-comprehensive scope of expected activities, getting from the discussions on the eventual fate of work and their interviews with specialists. They center primarily around those activities that can proactively shape a superior future yet can likewise frame the center principles of savvy responses inside every future situation world: labor force re-skilling, instruction frameworks change, improved advanced admittance, lithe wellbeing nets, work assurance motivators, shrewd occupation creation impetuses, backing to mass business venture, administration of online stage work, portability the executives, interest motivations.

The report, Working From Home - from invisibility to decent work (ILO, 2021), likewise shows that homeworkers don't have similar degree of social assurance as different specialists. They are additionally less inclined to be essential for a trade association or to be gotten by an aggregate wrangling ascension. The report joins solid proposals to make homeworking more noticeable and, in this manner, prevalent got. For modern homeworkers, the report underlines the meaning of urging their transition to the proper economy by broadening lawful assurances, improving consistence, summing up formed agreements, giving admittance to government managed retirement and making homeworkers aware of their privileges. For telecommuters, the report approaches policymakers to place specifically exercises to moderate psychosocial dangers and present a "option to detach", to ensure respect for the limits between working life and private life.

In the position paper from the International Federation of Robotics, it is emphasized that they believe that, robots increase productivity and competitiveness and increased productivity can lead to increased demand, creating new job opportunities. Also, it is pointed that automation has led overall to an increase in labour demand and positive impact on wages and therefore robots complement and augment labour. They pointed that the future will be robots and humans working together and that the robots substitute labour activities but do not replace jobs. Also, the focus of the report is that automation provides the opportunity for humans to focus on higher-skilled, higher-quality and higher-paid tasks (IFT, 2020).

\section{TECHNOLOGICAL CHANGES AND CHALLENGES - HOW MIGHT OCCUPATIONS AND JOBS CHANGE?}

Today, remote work has gotten the "new normal" and organizations and organizations are making it a piece of their drawn out procedures to guarantee business congruity. In the Republic of North Macedonia, the Economic Chamber of Information and Communication Technologies - MASIT held a data meeting to introduce the report about the discoveries of the investigation for the requirements of the ICT business for a gifted labor force as perhaps the greatest test for keeping up intensity and expanding development (MASIT, 2020).

This Workforce Assessment Report provides a comprehensive picture of the constraints and challenges of the companies in the ICT industry, in the region of Western Balkans, in relation to skills and availability of labor they need to operate effectively and to grow and to offer recommendations for improvements. The methodology includes: online survey of 134 ICT companies, direct interviews with ICT companies, direct interviews with business associations and data from State Statistical Offices of Individual Countries and also data from other available reports and studies (including WTO, World Bank etc.).

Regarding the question of Availability of labor force in the next three years, this report shows (especially survey from the IT companies -134) that they believe there will be no competent and well-trained workforce in the next three years. Analyzing the data from the Macedonian State Statistical Office, in the third quarter of 2020, the job vacancy rate was $1.69 \%$. The job vacancy rate was highest in section I - Accommodation and food service activities, $4.69 \%$, while the lowest rate was registered in sections D - Electricity, gas, steam and air conditioning supply and $\mathrm{O}$ - Public administration and defense; compulsory social security, 0.17\%. Business entities with 3-9 workers had the most job vacancy rate of $2.44 \%$. 
Table 3. Occupied Posts and Job Vacancies by Sectors of Activities

\begin{tabular}{|c|c|c|c|c|}
\hline $\begin{array}{l}\text { Number of } \\
\text { Occupied } \\
\text { Posts, } 2019\end{array}$ & \begin{tabular}{|} 
Number of Job \\
Vacancies, \\
2019
\end{tabular} & Sector of Activities & $\begin{array}{l}\text { Number of } \\
\text { Occupied } \\
\text { Posts, } 2020\end{array}$ & $\begin{array}{c}\text { Number of Job } \\
\text { Vacancies, } \\
2020\end{array}$ \\
\hline 508810 & 7791 & Total & 485372 & 8364 \\
\hline 4022 & 27 & Mining and quarrying & 4220 & 187 \\
\hline 120549 & 2003 & Manufacturing & 115863 & 2317 \\
\hline 7939 & 15 & Electricity, gas, steam and air conditioning supply & 8248 & 14 \\
\hline 10822 & 59 & Water supply; sewerage, waste management and remediation activities & 10124 & 80 \\
\hline 29570 & 355 & Construction & 29755 & 617 \\
\hline 86253 & 1420 & Wholesale and retail trade; repair of motor vehicles and motorcycles & 84658 & 1543 \\
\hline 30425 & 511 & Transportation and storage & 28910 & 627 \\
\hline 24426 & 813 & Accommodation and food service activities & 19133 & 941 \\
\hline 15113 & 320 & Information and communication & 15428 & 376 \\
\hline 10616 & 122 & Financial and insurance activities & 9699 & 85 \\
\hline 2374 & 78 & Real estate activities & 2320 & 21 \\
\hline 16329 & 189 & Professional, scientific and technical activities & 17641 & 254 \\
\hline 20855 & 742 & Administrative and support service activities & 22982 & 758 \\
\hline 39654 & 116 & Public administration and defense; compulsory social security & 28141 & 47 \\
\hline 35617 & 237 & Education & 35765 & 176 \\
\hline 36950 & 402 & Human health and social work activities & 36423 & 171 \\
\hline 12444 & 267 & Arts, entertainment and recreation & 11854 & 100 \\
\hline 4851 & 117 & Other service activities & 4208 & 50 \\
\hline
\end{tabular}

Source: Republic of N. Macedonia. State Statistical Office. Job vacancies, third quarter 2019, Source: State Statistical Office. Job vacancies, third quarter 2020.

Deriving from this data (Table 1), we could notify the following remarks comparing years 2019 and 2020 ;

1. For all sectors:

- The total number of occupied posts in 2020 has been decreased by $4.61 \%$.

- The total number of job vacancies in 2020 has been increased by $7.35 \%$.

Graph 1. Total Number of Occupied Post For All Sectors Graph 2. Total Number of Job Vacancies For All Sectors

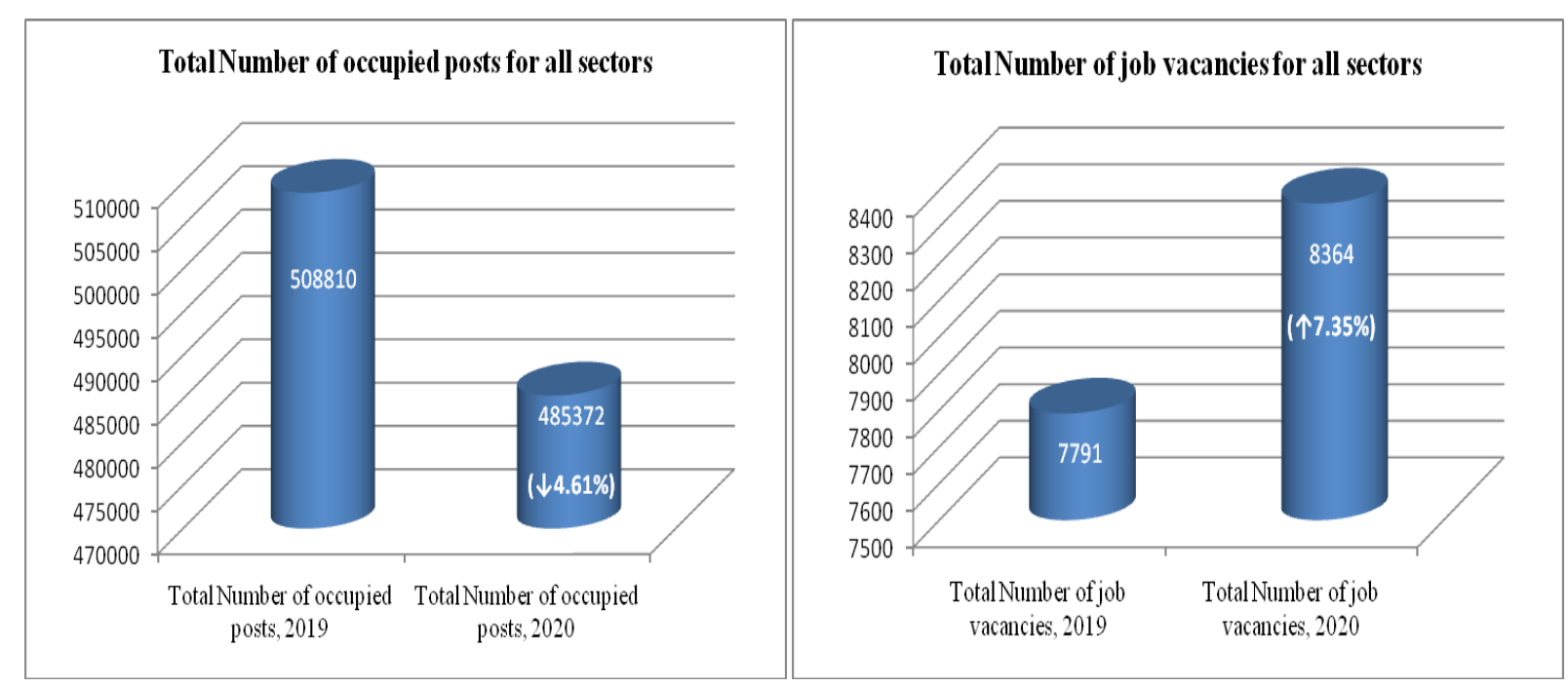




\section{Particularly for Sector Information and Communication Technology;}

- The total number of occupied posts in 2020 has been increased by $2.08 \%$.

- The total number of job vacancies in 2020 has been increased by $17.5 \%$, which means that there is a lack of qualified workforce for this sector.

Graph 3. Total Number of Occupied Post for IC

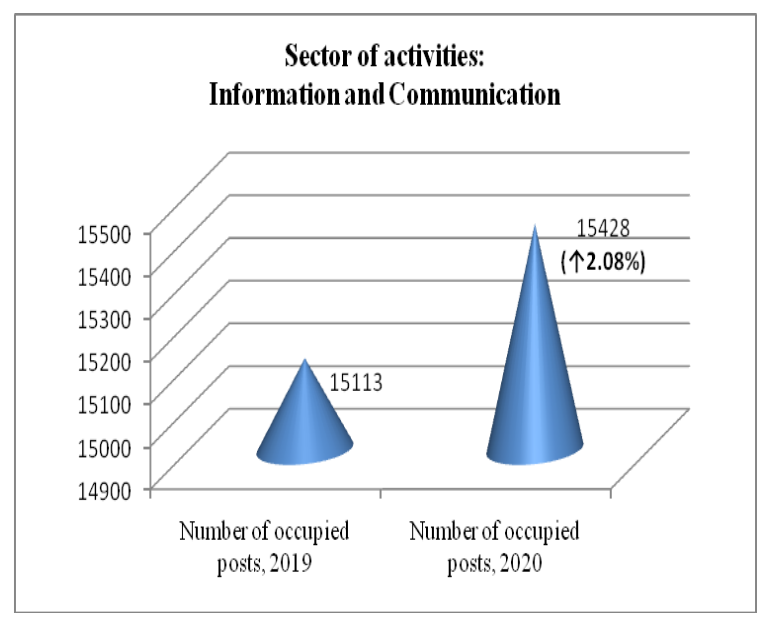

Graph 4. Total Number of Job Vacancies for IC

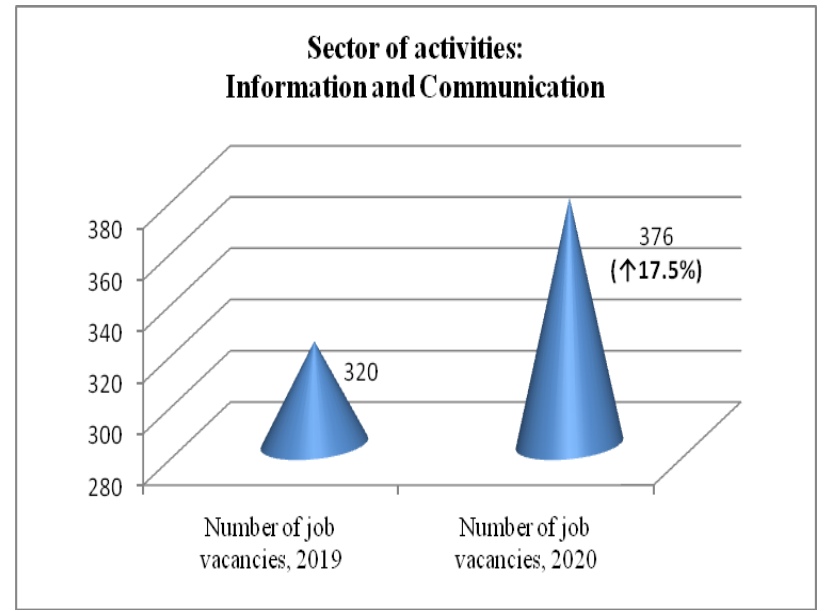

The paper also presents one short analysis of job vacancies (in Table 4) in accordance with the vacancies published for the Employment Agency for January 2021. The number of published job vacancies (selected vacancies for the ten most vacancies in January 2021) and their number is 600 . The announcements for the following vacancies are presented in Table 4.

Table 4. Number of Job Vacancies in January 2021 (By Occupation)

\begin{tabular}{|c|c|c|}
\hline Row & Occupation & No \\
\hline 1 & Seller & 59 \\
\hline 2 & Administrator/Administrative Officer & 42 \\
\hline 3 & Driver & 38 \\
\hline 4 & General worker & 37 \\
\hline 5 & The waiter & 20 \\
\hline 6 & Hygienist & 17 \\
\hline 7 & Doctor of medicine & 16 \\
\hline 8 & Sewing & 16 \\
\hline 9 & Construction & 15 \\
\hline 10 & Pharmacist & 12 \\
\hline
\end{tabular}

\section{CONCLUSION}

In the title of this paper, we say remote or hybrid generation, because of that terms we give definition about remote work and hybrid work force. Remote work will remain a cornerstone of the postpandemic future of work. One of the definitions about remote working is that remote working is a method of work that grants representatives of an association to play out the entirety of their principal work obligations from outside conventional office space. Making a hybrid workforce isn't difficult, but it does require a well-thought strategy. Each person component needs to work for both onsite and remote employees. And the key components together should support organizational culture, which in turn drives engagement and productivity.

The struggle to create jobs is becoming a key strategy for consolidating each country on a global scale. The analysis in this theoretical paper provides a detailed overview of labor market developments in N. Macedonia. The movements of the basic indicators for the labor market market and employment by certain activities are analyzed. The analysis of the trends in the Macedonian labor market indicates the concern that the combinet 
impact of demographic factors and structural mismatch between supply and demand affects the flexibility and mobility of the workforce.

Research and analysis of the labor force in N. Macedonia is a subject that is always subject to significant changes in society and because of this is the urgency and need for this research challenge. According to the analyzed data and the comparative analysis of the workforce and jobs, it is inevitable to emphasize that it needs an appropriate combination of skills that are in accordance with the requirements of the national and regional economies.

One of the reccomedation is that in the future, organizations and competent institutions in N. Macedonia should enable retraining (requalification) opportunities for people who want to change career paths, improve on the job training, establish procedures and culture of collaborative learning, job shadowing, reparative activities for education and training in the areas that are expected to be dominant in the following period, such as: artificial intelligence, internet of things, Big Data, virtual reality, robotics and promotion of life-long learning and collaborative learning on all levels of education.

It is necessary in next period the associations in N. Macedonia must to zero in on work done rather than hours worked-making devices and applications to help oversee far off worker execution more essential. Also, ceaseless criticism will become fundamental since chiefs should endeavor to assist representatives with exploring their work duties and meet execution assumptions. It will be vital reexamining how objectives are set and distinguishing key execution measurements that will be basic to overseeing telecommuters in the new typical. Exclusively by dynamic partaking in virtual occasions, being dynamic in online gatherings, and keeping eagerness high, workers will actually want to stand apart as pioneers while working from home.

\section{REFERENCES}

BLAZEVSKI - MOJSOSKA, N ve PETRESKI, M (2015), Assessment of the Impact of the Active Labor Market Programs: Key Findings, Decent Technical Support Team Work and Office of Central and Eastern Europe, ILO

CITRIX (2020a), "The State of Remote Work Preparing For Business as Usual-From Anywhere", E-Book, https://www.citrix.com/content/dam/citrix/en_us/documents/ebook/the-state-of-remote-work.pdf (Date of Access: 18.12.2020).

CITRIX (2020b), “Work 2035 - How People And Technology Will Pioneer New Ways of Working”, Analyst Report, https://www.citrix.com/content/dam/citrix/en_us/documents/analyst-report/work-2035.pdf (Date of Access: 05.01.2021).

DELOITTE INSIGHTS (2019), Leading the Social Enterprise: Reinvent With a Human Focus - 2019 Deloitte Global Human Capital Trends, Deloitte Insights Publisher, New York (USA), https://www2.deloitte.com/content/dam/Deloitte/ro/Documents/HC_Trends_2019_C_TT-FFF06291_ro_2019_General_Document_en.pdf?nc=1\&utm_campaign=HC_Trends_2019_C_TT-FFF06291_ro_2019_General_Email_en\&utm_medium=email\&utm_source=Eloqua (Date of Access: 20.12.2020).

EMPLOYMENT AGENCY OF THE REPUBLIC OF NORTH MACEDONIA (2019), Labor Market Skills Needs Survey in the Republic of Northern Macedonia for 2020, Results of the conducted research, Skopje: Employment Agency of the Republic of Northern Macedonia.

EMPLOYMENT AGENCY OF THE REPUBLIC OF NORTH MACEDONIA (2021), "Ad Search", Employment Agency of The Republic of Northern Macedonia Corporate Web Page, https://erabota.av.gov.mk/OglasSearch.aspx (Date of Access: 28.01.2021).

HELSINKI COMMITTEE FOR HUMAN RIGHTS OF THE REPUBLIC MACEDONIA (2019), Measuring the level of satisfaction with the mechanisms for protection of workers' rights in the Republic of North Macedonia, Skopje.

ILO - INTERNATIONAL LABOUR ORGANIZATION (2021), Working From Home: From Invisibility to Decent Work, ILO Publisher, Geneva, https://www.ilo.org/wcmsp5/groups/public/---ed_protect/--protrav/---travail/documents/publication/wcms_765806.pdf (Date of Access: 12.01.2021). 
INTERNATIONAL LABOUR ORGANIZATION 2020. COVID-19 and the World of Work: Rapid Assessment of the Employment Impacts and Policy Responses. North Macedonia. First Edition. May 15, 2020. https://www.ilo.org/budapest/whatwedo/publications/WCMS_746124/lang--en/index.htm. (Date of Access: 15.01.2021).

MACEDONIA 2025. The Impact of the COVID-19 Pandemic on Enterprises in North Macedonia. May 2020. https://socijalendijalog.mk/wp-content/uploads/2020/08/ENG-Reporton-the-impact-of-COVID-19-FINALrev-4-17-8-20.pdf. (Date of Access: 12.01.2021).

MASIT (2020), ICT - Labor Force Assessment Report, Workforce Assessment Report - ICT Industry, https://masit.org.mk/en/publications_post/report-on-the-topic-ict-labor-force-assessment-report/ (Date of Access: 03.01.2021).

POMPA, Claudia (2015), Jobs for the Future, Report, https://www.odi.org/sites/odi.org.uk/files/odiassets/publications-opinion-files/9578.pdf (Date of Access: 15.12.2020).

STATE STATISTICAL OFFICE (2019), Job Vacancies, Third Quarter 2019, http://www.stat.gov.mk/pdf/2019/2.1.19.32_mk.pdf (Date of Access: 09.01.2021).

STATE STATISTICAL OFFICE (2020), Active Population in the Republic of N. Macedonia Results from the Labour Force Survey, III quarter 2020, http://www.stat.gov.mk/pdf/2020/2.1.20.34_mk.pdf (Date of Access: 23.12.2020).

STATE STATISTICAL OFFICE (2020), Job Vacancies, Third Quarter 2020, http://www.stat.gov.mk/pdf/2020/2.1.20.33_mk.pdf (Date of Access: 10.01.2021).

TRAJKOVSKI, K (2019), National Report: Adapting Industrial Relations to New Forms of Work, Center for Research and Policy Making, Skopje.

WORLD ECONOMIC FORUM (2018), Eight Futures of Work - Scenarios and Their Implications, World Economic Forum Publisher, http://www3.weforum.org/docs/WEF_FOW_Eight_Futures.pdf (Date of Access: 10.12.2020).

WORLD ECONOMIC FORUM (2020), The Future of Jobs Report 2020, World Economic Forum Publisher, http://www3.weforum.org/docs/WEF_Future_of_Jobs_2020.pdf (Date of Access: 10.01.2021). 